\title{
POR UM EROS FURIOSO E TERNO: UMA ABORDAGEM POÉTICA CONTEMPORÂNEA DO MITO DE EROS NO LIVRO BOLHA DE LUZ, DE HERMÍNIO BELLO DE CARVALHO
}

Marcelo Maldonado Cruz*

RESUMO: O mito de Eros encontra-se nas raízes das investigações a respeito do sentimento do amor e das maneiras como se exprime no homem. Tal como idealizado por Platão em $O$ banquete, ressurge representado através dos tempos em praticamente todas as manifestações artísticas ocidentais, principalmente na poesia. Hermínio Bello de Carvalho, poeta carioca, vai retomar, no livro Bolha de /uz, de 1985, o Eros socrático e conferir-Ihe uma identidade contemporânea, transfigurando-o na imagem do marginal terno. Ao analisar as imagens integrantes do discurso poético à luz dos pressupostos teóricos desenvolvidos por Gilbert Durand, chega-se uma releitura do mito de Eros na qual se verifica uma profunda identificação com a vigência do regime noturno do imaginário simbólico do homem.

PALAVRAS-CHAVE: Poesia brasileira; Poética; Mito; Símbolos; Imaginário
* marcelo.cruz@acad.pucrs.br

Mestrando em Letras - Escrita Criativa - pela Pontifícia Universidade Católica do Rio Grande do Sul (PUCRS) - Bolsista CNPq

ABSTRACT: The Eros myth is found in the roots of all research about love and its forms of expression in mankind. As idealized by Plato in his Symposium, resurfaces represented through the ages in virtually all Western art forms, especially in poetry. The Brazilian poet Hermínio Bello de Carvalho takes a new look at the Socratic Eros and gives it a contemporary identity, transforming it into the figure of a gentle outsider, in his 1985 book Bolha de luz. By analyzing the images of this poetic discourse in light of the theory developed by Gilbert Durand, we achieve a new reading of Eros myth in which there is a deep identification with the nocturnal regime of human's symbolic imagery.

KEYWORDS: Brazilian poetry; Poetics; Myth; Symbols; Imaginary 


\section{I - DO POETA}

Hermínio Bello de Carvalho poeta precedeu o compositor-letrista, autor de canções famosas como Alvorada Mudando de conversa, Sei lá, Mangueira e Timoneiro, entre outras. Nascido no Rio de Janeiro, em 1935, estreou em livro em 1961, com Chove azul em teus cabelos, seguido por Ária \& percussão, em 1962, e Argamassa, dois anos depois, todos eles volumes de poemas. Publicou em 1963 uma conferência sobre Villa-Lobos e, em 1967, um libreto de ópera popular em parceria com o compositor Maurício Tapajós, intitulado João-Amor e Maria.

Nessa mesma época já estava profundamente engajado na cena musical carioca, tendo ajudado a idealizar o Zicartola um misto de bar, restaurante e casa de espetáculos que funcionou durante cerca de um ano e meio, de 1963 a 1965, num sobrado da Rua da Carioca, de propriedade do compositor Cartola e sua esposa, Zica. No Zicartola reuniam-se importantes nomes do samba da cidade e foram gerados os projetos de espetáculos emblemáticos como o Opinião, em 1964 - uma idealização de Zé Keti que ganhou texto de Oduvaldo Viana, Armando Costa e Paulo Pontes e direção de Augusto Boal -, e o Rosa de Ouro, no ano seguinte, escrito e produzido pelo próprio Hermínio, que apresentou ao grande público a cantora Clementina de Jesus e promoveu o ressurgimento de Aracy Cortes, veterana atriz e cantora dos teatros de revista.
A partir daí, o poeta deu lugar ao empreendedor cultural que, entre incontáveis produções de espetáculos, discos e a idealização de projetos como o Pixinguinha, passou a dar especial atenção ao exercício de letrista, colocando sua verve lírica a serviço da composição de canções populares. Aos livros voltaria apenas em 1973, com Amor, arma branca, e, em 1985, com Bolha de luz.

Bolha de luz foi lançado em tiragem particular para a comemoração dos 50 anos de Hermínio e era acompanhado por um disco compacto simples, de sete polegadas, contendo canções em parceria com Cacaso, Vital Lima, Cláudio Jorge e Maurício Tapajós. No livro, o poeta retomaria alguns temas recorrentes em seus trabalhos anteriores, sobretudo aqueles relacionados à entrega amorosa e ao erotismo, desta vez condicionados a um maior rigor técnico, estético e imagético.

\section{II - DA TEMÁTICA}

Bolha de luz marca a volta de Hermínio Bello de Carvalho à escrita poética poesia mais de uma década depois de Amor, arma branca, período no qual dedicou-se quase que exclusivamente às atividades no ramo da produção cultural e à composição de letras para canções populares. Esse retorno retoma as reflexões a respeito de temas muito caros ao poeta: os meandros e desvãos da entrega amorosa, da manifestação da afetividade e do erotismo, bem como as personagens habitam esses espaços. 
No tratamento desses temas, há uma concepção que se estabelece como uma espécie de fio condutor para a construção do imaginário poético: a noção de que a disposição afetivo-amorosa-erótica do homem está atrelada a um condicionamento de lugares que ora permite, ora proíbe a sua manifestação. Duas esferas são imediatamente estabelecidas e contrapostas: uma privilegia a "normalidade", isto é, tudo aquilo que se enquadra numa ordem social, política e religiosa que determina o ser-estar-fazer-pensar-agir do homem de acordo com preceitos que não comportam insubmissões de qualquer espécie; a outra abriga a exceção, a anomalia, a loucura, o caos no qual se originam o pensamento, os sonhos, a aleatoriedade, a imprevisibilidade, o acaso, ou seja tudo aquilo que não converge para uma relação distinta de causa e efeito e que foge aos padrões de qualquer classificação racional. O poeta estabelece essa distinção no terceiro poema do livro:

Tem dias que amanheço

o olho pardo e sofrido;

e uma fome mastigando

as várzeas onde me habito.

Golpeio meu próprio corpo

que nem um galo na rinha

e que tira do outro galo

uma lasca insubstituível.
Tem dias que empardeço

e a tarde é um sacrifício:

por dentro de mim escurece

e não me domo, sozinho.

E repasso minhas coxas

e as aliso e me lixo

e do corpo extraio um sumo

e oficio a santa missa.

Tem noites em que eu clareio

e a vida toda alumio:

e me desfaço das teias

que as aranhas construíram.

Desamarro o prisioneiro

que dentro de mim havia

e de bruços vou ao pote

que me sacia, e o sacio ${ }^{1}$

O desejo esbarra nos rigores de uma ordem social calcada eminentemente em princípios religiosos que o impedem de irromper plenamente, estancando a sua força criadora e libertária. A fome que ele causa não se pode saciar à luz do dia; há que se aguardar que as sombras da noite favoreçam todo o movimento de libertação das teias enquanto símbolo de uma realidade aprisionadora, repressiva, para que, enfim, possa se dar a satisfação de suas exigências. 
2. DURAND. As estruturas antropológicas do imaginário, $\mathrm{p}$
Em As estruturas antropológicas do imaginário, Gilbert Durand desenvolve o estudo dos significantes expressos pelos símbolos fundamentais da imaginação humana. Para levar a termo tarefa tão complexa quanto monumental, partiu da definição das categorias de motivação dessa imaginação simbólica, tanto em dados psicológicos do comportamento humano quanto em suas relações sociais.

Basicamente, essa motivação encontra suas raízes nas relações reversíveis entre homem e natureza - entendidas a partir da noção de cultura, pois que significa, numa instância básica, a modificação do meio natural pela ação humana -, em cujo intervalo são geradas reciprocamente essas formulações simbólicas.

Afinal, o imaginário não é mais que esse trajeto no qual a representação do objeto se deixa assimilar e modelar pelos imperativos pulsionais do sujeito, e no qual, reciprocamente, como provou magistralmente Piaget, as representações subjetivas se explicam "pelas acomodações anteriores do sujeito" ao meio objetivo. [...] Podemos dizer, parafraseando a equação de Lewin, que o símbolo é sempre o produto dos imperativos biopsíquicos pelas intimações do meio.

No que diz respeito a práxis poética, as investigações de Durand vão afirmar a "primazia do sentido simbólico (ou figurado), considerando que o figurado não é um epifenômeno ou um ornamento que recobre uma significação positiva, mas o elemento cuja hermenêutica revela a face obscura, noturna e profunda da linguagem, desveladora da intimidade subjetiva”. ${ }^{3}$ A escrita poética vai se debruçar sobre as imagens que cria mediante o manejo de uma linguagem cujo discurso, eminentemente simbólico, "afigura-se como a expressão, tradução ou interpretação criativa de uma infraestrutura, de uma protolinguagem ou de uma vivência profunda".

No inventário simbólico humano, Durand vai identificar dois regimes distintos de representação: o diurno e o noturno. No diurno predominam as ações e imagens conectadas com todas as aspirações de elevação, distinção e glória; no noturno vão prevalecer as que se ligam à intimidade e ao retorno ao seio materno. Em sua obra, Durand vai organizar um "quadro com um possível agrupamento dos símbolos consoante revelem os regimes diurno e noturno do imaginário, entendendo-os como produtos da relação entre os reflexos inconscientes da sensório-motricidade humana e as pressões do meio social". ${ }^{5}$ Em Bolha de luz, toda a questão do desejo, da afetividade e do erotismo se desenvolve a partir da vigência desses dois regimes, nos quais se configura ora a interdição, ora a permissão à sua manifestação plena.

A definição do amor é uma tarefa a que o homem dedica intermináveis considerações e tentativas de conceituação
3. MELLO Poesia e imaginário p.

4. MELLO Poesia e imaginário p.

5. MELLO. Poesia e imaginário, $\mathrm{p}$.
EM TESE
BELO HORIZONTE
v. 22
N. 2
MAIO-AGO. 2016
CRUZ. Por um Eros furioso e terno: Uma abordagem poética [...]
P. $197-212$ 
em todas as esferas do pensamento, desde que, entre os gregos, Platão elaborou um de seus mais famosos diálogos: o Banquete. O comportamento erótico do homem, bem como suas implicações, tanto físicas quanto anímicas, tornou-se um problema de múltiplas faces ou uma figura geométrica de $n$ lados, cuja simetria nem sempre lhe é cara.

Em Banquete, Sócrates tenta lançar luz sobre as diversas concepções de Eros apresentadas pelos outros convivas utiliza-se de um artifício engenhoso ao atribuir à misteriosa Diotima a responsabilidade de lhe ter ensinado tudo o que sabia sobre o amor. Assim, aparentemente sem se apropriar da autoria do próprio discurso, Sócrates incute na consciência de seus amigos a sua ideia de um Eros demiúrgico, sempre pobre, longe de ser delicado e belo, mas duro, seco, descalço e sem lar, sempre por terra e sem forro, deitando-se ao desabrigo, às portas e nos caminhos. Essas características lhe seriam devidas por parte de mãe:

Por outro lado, como filho de tal pai, vive a excogitar ardis para apanhar tudo o que é belo e bom; é bravo, audaz, expedito, excelente caçador de homens, fértil em ardis, amigo da sabedoria, sagacíssimo, filósofo o tempo todo, feiticeiro temível, mágico e sofista. Por natureza, nem é mortal nem imortal, porém num só dia floresce e vive, ou morre para renascer logo depois, quando tudo lhe corre bem, de acordo, sempre, com a natureza paterna. O que adquire hoje, perde amanhã, de for- ma que Eros nunca é rico nem pobre e se encontra sempre a meio caminho da sabedoria e da ignorância. $(203 \text { d-e })^{6}$

Essa duplicidade encontrada no Eros socrático é a mesma transposta para o discurso poético que permeia os versos de Bolha de luz. Por intermédio de um imaginário simbólico cuidadosamente construído ao longo dos 17 poemas que compõem o livro, surge uma nova personagem para ocupar o lugar da figura mítica tradicional, descrita por Platão. O poeta evoca o Eros ancestral para lhe conferir uma identidade contemporânea, confirmando o poder renovador da linguagem poética na tarefa de oferecer novas leituras a temas clássicos, como acertadamente esclarece Durand:

A poesia contemporânea define-se como uma re-evocação pelo verbo de um «sentido» senão mais puro, pelo menos mais autêntico, conferido às palavras pelo grupo social. É como se o poeta contemporâneo, imerso na civilização tecnicista das grandes cidades, reanimasse subitamente, pelo jogo da sua linguagem, os arcanos dos grandes mitos.?

Essa é uma das possíveis chaves de leitura para a poesia de Hermínio Bello de Carvalho em Bolha de luz, para a qual recorre-se a conceitos como os de imagem, símbolo e mito a fim de se compreender a pluralidade de significados resultante de sua tessitura textual.
6. PLATÃO. O banquete - Apologia de Sócrates, p. 65, 66. 
8. CARVALHO. Bolha de luz, p. 5 .

9. CARVALHO. Bolha de luz, p. 5

\section{III - O MARGINAL TERNO: UMA RELEITURA DO MITO}

\section{DE EROS}

A figura do marginal terno, tal como o poeta vai tecer ao longo do livro, emerge aos olhos do leitor primeiramente identificada a uma pessoa de hábitos / estranhos e movediços / que se abrigava na chuva / e conversava com deus / e replantava gerânios / onde nem jardim havia. ${ }^{8}$ Essa personagem descrita no poema de abertura, intitulado Sete chaves, estabelece uma característica que soará comum aos tipos descritos nos poemas seguintes: a inadequação.

O isolamento proveniente desta inadequação é outra particularidade importante, pois une as pontas do livro e cons tata a relutância em se entregar. A sua essência (a que é hoje e a que um dia foi) tranca-se vigorosamente por dentro de si e só ele é capaz de denunciá-la ou de revelá-la. Este primeiro poema do livro liga-se ao último, intitulado $A$ chave do alçapão, cuja mensagem enuncia claramente o desejo de não se revelar, e remete para esse universo íntimo e resguardado ao qual jamais se tem acesso, mesmo quando se oferece a chave da casa.

Dá-se a casa, mas a chave fica por dentro da gente trancando com certa raiva as coisas que lá ficaram. ${ }^{9}$
Sob sete chaves repousa a morada, o corpo, o íntimo, o abrigo indevassável a que o homem se recolhe a fim de preservar a si mesmo, a simbologia do mistério a ser penetrado. De qualquer forma, dando-se a casa ou a chave, rendendo-se ao tempo ou às mudanças de valores, algo fica por dentro dele, seja a saudade de um outro tempo ou de outras pessoas, a lembrança de coisas palpáveis ou de sensações ternas que ficaram há muito perdidas - a casa de quartos desajeitados, onde havia abrigo e compreensão.

A casa constitui, portanto, entre o microcosmo do corpo humano e o cosmo, um microcosmo secundário, um meio-termo cuja configuração iconográfica é, por isso mesmo, muito importante no diagnóstico psicológico e psicossocial. [...] E as confidências sobre o habitat são mais fáceis de fazer do que sobre o corpo ou sobre um elemento objetivamente pessoal. Os poetas, os psicanalistas, a tradição católica ou a sabedoria dos dogon fazem coro para reconhecer no simbolismo da casa um duplicado microcósmico do corpo material e do corpo mental. Os quartos da casa equivalem a órgãos, nota Beaudoin, e espontaneamente a criança reconhece nas janelas os olhos da casa e pressente as entranhas na adega e nos corredores. ${ }^{10}$

No poema Metades, é nitidamente visível o tema do duplo - um deles banhado na luz, outro imerso na treva - que significa uma outra maneira de se enunciar a prevalência
10. DURAND. As estruturas antropológicas do imaginário, $\mathrm{p}$. 
12. CARVALHO. Bolha de luz, p. 27.

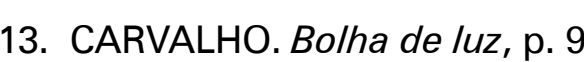

dos sistemas diurno e noturno do imaginário, pressuposto básico em que se apoiará a poética de Bolha de luz:

Metade feita de açúcar

a outra metade, a que azeda:

um amanhece em bom-dia

o outro desperta na merda. ${ }^{11}$

Tal qual ocorre com a figura de Eros descrita no Banquete; as metades convergem, vivem uma na outra, e tornam-se responsáveis pelo inevitável conflito interior que estabelece o problema de identidade: vão no fundo é carregando/ lixo, remorso, entulho. ${ }^{12} \mathrm{O}$ paradoxo é a consequência imediata desta duplicidade e acaba por permear todo o texto, praticamente do primeiro ao último poema do livro, contrapondo atributos próprios de ambos regimes, diurno e noturno.

Bolha de luz, o título, é igualmente significativo porque implica em duas ideias cujo paradoxo é, mais uma vez, a tônica central. O conceito de uma irradiação luminosa cerceada pelos limites de uma bolha remete novamente ao terceiro poema do livro, que, inspiradamente, elucida: Tem noites en que eu clareio/ e a vida toda alumio [...] / Desamarro o prisioneiro/ que dentro de mim havial e de bruços vou ao potel que me sacia, e o sacio. ${ }^{13} \mathrm{E}$ é este limite que marcará o eu lírico prisioneiro de si mesmo, de sua conturbada manifestação de erotismo, de um conflito íntimo de aceitação.
A permanente vigência de dois ambientes distintos na consciência poética põe em prática o que o título do livro já havia denunciado: a existência de uma luz aprisionada numa redoma transparente e que se destaca em meio à escuridão. Um dos ambientes privilegia a regra, o outro a exceção, como neste fragmento: Na jaula onde se encontra/ há quem o designe homem/ ou quem o nomeie viado. ${ }^{14}$ Quando vence a exceção, o prisioneiro é desamarrado e pode saciar-se; quando é a regra a vencedora, instaura-se a dura realidade cotidiana, em que a convivência com sentimentos conflitantes e conflituosos (nojo, raiva, fome, pavor, flagelo...) favorece uma espécie de masoquismo, de autopunição e a sensação de inconformidade com a ordem.

Por isso mesmo, posto que todo conflito interior compreende um certo quinhão de dor e sofrimento, a saciedade que se obtém é revertida em agressividade e em imagens que privilegiam o aspecto marginal do homem. Aparecem as alusões à loucura, aos ritos sagrados e a um certo masoquismo que salta propositalmente dos versos, talvez como penitência para a remissão da culpa ou ainda como acessório de pura volúpia, de gozo para os instantes de concretização do ato sexual. A sensualidade contida nas construções poéticas torna-se intensa, seguindo a orientação temática do livro. A sexualidade é conturbada, ora reprimida, ora permitida, porém sempre carregada de um sentido dúbio e escuso, procurando a melhor forma para expressar-se, sem, contudo, ferir convenções e convicções íntimas.

EM TESE

BELO HORIZONTE

v. 22

N. 2

MAIO-AG0. 2016

CRUZ. Por um Eros furioso e terno: Uma abordagem poética [...]

P. $197-212$ 
Como tantos outros poetas ao tratar o erotismo, Hermínio Bello de Carvalho recorre a um certo refinamento verbal, por vezes rebuscado, que parece querer erotizar a própria palavra, consciente de que é através dela que tanto vislumbra-se o contorno (erótico ou não) do objeto desejado quanto realiza-se a entrega final, a posse definitiva, passando, é óbvio, pela interminável sedução deste mesmo objeto. Aqui, este recurso verifica-se no contraponto de palavras cujos campos semânticos ora divergem - como a própria personalidade dos amantes - ora convergem para uma orgia plena de significados.

O cuidado estético persegue igualmente o verso, que se encaixa num metro próprio, sincopado, como o ritmo do corpos na cópula. Este rigor, representado pelo verso em redondilha maior, admite, no entanto, oscilações entre versos de seis ou oito sílabas, sem, porém, extrapolar este limite, conferindo ao todo poético um fraseado linear e constante. Aprisionado dentro das regras da métrica, o verso - assim como o homem reprimido que, para fazer valer a sua vontade e saciar os desejos, burla a rigidez das normas sociais - luta para libertar-se, como neste fragmento:

Mas cola insuficiente a ma-

lha: e o espelho desnua. ${ }^{15}$
A exceção é Retrato, em que o verso revela-se, finalmente, livre. E é neste poema que o poeta descreve a figura do marginal por excelência, cuja vida imersa no caos estabelece o cânone erótico:

Ele movia as luas com o dedo dos olhos e bebia nos alambi[ques a borra

mais crespa dos vinhos.

E se servia dos tachos mais escuros e com uma estranha [pressa, e aos

sussurros e suspirando fundo a que não o ouvissem.

E tinha quase tudo para ter o mundo que sonhava, mas só [que sonhava

o refugo e o lixo: elegendo as matérias mais espúrias por uma questão de fado e predestino.

E habitava os telhados e seu miado

lá no fundo dos estômagos percutia. E se dobrava como se [dobram os

sinos das igrejas do interior quando morria alguém que à [cidade merecia.

E recolhia o lixo de si mesmo com a espátula dos outros e o sabugo das unhas negras denunciava a procura do que esmiucava, aos nervos,

mas com doçura;

pois a doçura é que o consumia.

As cáries habitavam os seus dentes e uma agonia 
perpassava-lhe o sono; e quando dormia

dormiam com ele os morcegos e os ratos e os mendigos e o

[pão de véspera

e os cães vadios e qualquer imundo a quem unhava as costas

[e acendia

uma vela a Deus, outra ao Diabo

mas era só o Diabo quem o ouvia:

Deus sempre lhe fez ouvido moco

e às preces carcomidas que gania

$$
\text { louco. }
$$

E palmilhava as bordas da lua e mordiscava a fuligem das

[estrelas que esculpia

na espuma do chope que lhe ofereciam.

E desabotoava os botões dos anjos e esculpia em jorros bran[cos sua própria armadilha

\section{e trôpego em seu cavalo ele sumia}

prometendo voltar, e se voltava (um dia sempre voltava)

tinha o paramento esburacado como se houvesse

atropelado um deus em sua fúria. ${ }^{16}$

É a recuperação do Eros socrático, belo e grotesco, sublime e mesquinho, sábio e louco, como o Bobo das cartas de Tarô. Ao ter a sorte já selada, ele assume o mesmo caráter de impunidade das vítimas escolhidas para os sacrifícios humanos, destinadas a atrair o favor divino, agradecer a uma graça recebida ou expiar uma culpa. Ao Louco tudo é permitido, pois conta, além da irresponsabilidade e irreflexão próprias de sua natureza, com a indulgência que normalmente a sociedade tem para com os de sua condição. Vive num mundo próprio, incomunicável, de símbolos e essências pertinentes somente à sua lógica singular, em que a profunda ruptura com todas as relações anteriores - familiares, sociais e afetivas - é a base de todas as suas ações. Desta forma, também não é justo pedir-lhe juízos estéticos acurados, pois o seu comportamento varia do lixo ao luxo.

Também são loucos os poetas e os iniciados, pois carregam em seu íntimo a chave da transcendência; o limite da palavra; a soma que atinge o vazio; "a presença superada, que se transforma em ausência; o saber último, que se torna ignorância, disponibilidade: a cultura, aquilo que fica quando tudo o mais é esquecido". ${ }^{17}$ Por isso, ante a figura do louco, o poeta se curva:

Os loucos, sei que os entendo.

Por acaso quem me sonha

os pesadelos que tenho?

quem acorda aos sobressaltos

participando do enredo

das lutas em que me embrenho

em meu sono pavoroso?

quem adoece risonho
17. CHEVALIER; GHEERBRANT. Dicionário de símbolos, p. 560 
senão eu, com vil disfarce?

quem oculta sob a face

a lâmina enferrujada

que abate os bois em silêncio?

Não me pensem um maldito

que traça insônia a medo

e a carrega em alforje.

E se mordo os travesseiros

é para abafar os gritos

que os armazeno: azedos.

E são gritos pavorosos

que ecoam pelos meus sonhos.

Aos loucos eu os acolho

porque a eles entendo. ${ }^{18}$

Este é o personagem eleito para a personificação de Eros em Bolha de luz. Ao esculpir a imagem do ser que volun tariamente habita um cenário repugnante, por uma questão de fado e predestino ${ }^{19}$, o poeta adere ao inevitável destino da figura do louco; daquele que tinha quase tudo para ter o mundo que sonhava, mas só que sonhava o refugo e o lixo, ${ }^{20}$ do iniciado num mistério cujo sentido fatalmente escapará aos olhos do homem comum. Por isso, porque não pode ser acompanhado pela razão, assume um caráter quase cômico em sua tragicidade, e sua presença, num universo em que o bom-senso é a regra, torna-se bastante estranha e incômoda.
As ações decorrentes de sua opção pelo 'caminhar à margem' trazem consigo toda a sua essência libertária e desconcertante contida no próprio Eros socrático; rude, mas insidioso com o belo, dormindo ao relento - com os morcegos, os ratos, os mendigos e os cães vadios - mas ávido de sabedoria. Os verbos próprios destas ações ocultam uma microverdade (ou um microuniverso) carregada da essência do eu lírico. A aridez do cotidiano jamais comportará a ultra sensibilidade dos personagens que, com seus gestos aparentemente sem sentido, tentam amenizar a sua própria inadequação à realidade. 'Abrigar-se na chuva' ou 'plantar gerânios onde nem jardim havia' marcam um corte de irrealidade no real, em que ações concretas como 'abrigar-se' ou 'plantar' servem de alimento para as antíteses. Ao mostrar a aparente incongruência, impossibilidade ou irracionalidade destas ações, o poeta insiste na contramão do real, endossando a atitude erótica perante a vida, fazendo brotar de um campo estéril algo concreto, novo e sensibilizado, buscando a gênese da ternura no caos.

A sua imagem, assim descrita, torna-se a representação do marginal furioso e terno, que caminha entre as convenções a mostrar-lhes as contradições; que se retorce em sonhos macabros e, ao mesmo tempo, consome-se em doçura; que empreende a caçada amorosa e jamais se entrega de fato; que luta descarnadamente contra a própria essência, conciliando 
as suas metades contrastantes; que alumia e goza plenamente para, no momento seguinte, remoer a suposta podridão. No entanto, não se deve esquecer que, assim como os conflitos coexistem em sua personalidade - o que causará, evidentemente, o eterno problema de identidade - há ainda o prestidigitador, o maquinador que, entre sofismas e disfarces, tece a sua interminável rede de sedução, capaz de ocultar-se no sofrimento e revelar-se na conquista.

No entanto, a entrega amorosa faz-se necessária e é por ela - e pelo seu avesso: a impossibilidade de se dar totalmente - que se conhecerá, ainda que difusamente, um pouco da personalidade deste marginal terno, deste Eros contemporâneo, atormentado por não poder exercer totalmente a sua (homo) sexualidade latente. Seu corpo todo estremunha luta aguerridamente consigo mesmo e acaba por ceder, não sem antes estabelecer o grau de perturbação interior que separa a existência e a satisfação do desejo, como em

Não ouso dizer às claras

o que esse visgo sufoca

quanto descosturo a pele

e arrebento o escapulário.

e o que é razão, enfim,

de eu viver qual aloprado

atirando fora a sopa

lambendo no escuro o prato. ${ }^{21}$
Para obter a saciedade, sem que isso implique em conflito com a norma vigente, o homem se vê obrigado a lançar mão do disfarce, das artimanhas eróticas da sedução, travestindo-as em símbolos e imagens particulares para articular, sempre na sombra, a sua manifestação sensual (e sexual). Entram em cena os cinco poemas nos quais o poeta, valendo-se da figura da aranha, personifica a possibilidade do disfarce como elemento preponderante ao sucesso da empreitada amorosa.

A simbologia na qual se insere a imagem da aranha é vastíssima e evoca, primeiramente, a fragilidade de sua própria teia como a de uma realidade de aparências ilusórias, enganadoras. É no mito grego de Aracne que se encontra a antiquíssima dialética essência/existência, em cujo confronto reside a significação profunda da imagem da aranha na cultura ocidental. Aracne, exímia tecelã, ousa desafiar a deusa Atena, que é a mestra e patrona da arte da tecelagem. Frente a frente, elas tecem seus bordados. Atena borda os deuses do Olimpo em toda a sua majestade e, nos quatro cantos de seu trabalho, recorda os castigos sofridos pelos mortais que ousaram desafiá-los. Em resposta, Aracne representa em seu bordado os amores dos deuses por mortais, o que evidentemente causa a ira de Atena. Golpeada pela deusa, Aracne decide se enforcar, mas sua vida é poupada pela própria Atena, que a transforma numa aranha. Como 
22. CHEVALIER; GHEERBRANT. Dicionário de símbolos, p. 71.

castigo por tentar rivalizar-se com um deus, Aracne tem a sua ambição demiúrgica punida.

Todas essas qualidades de demiurgo, de pressagiadora, de condutora de almas e, portanto, de intercessora entre os mun dos das duas realidades - humana e divina - fazem com que a aranha simbolize também um grau superior de iniciação. [...] Para o psicanalista, entretanto, essa interioridade evocada pela aranha ameaçadora no centro de sua teia é um excelente símbolo da introversão e do narcisismo, a absorção do ser pelo seu próprio centro (Beaudoin). ${ }^{22}$

O fato de serem em número de cinco os poemas que tratam da simbologia da aranha também é significativo. O número 5 é o símbolo do homem, tal como representado no clássico homem vitruviano, de Leonardo da Vinci: braços e pernas abertos, demonstrando as propriedades da proporção áurea, disposto em cinco partes (cabeça, braços, pernas e o peito, abrigo do coração). Também simboliza o universo em seus eixos vertical e horizontal que se cruzam num mesmo centro. Por último, estão por esse número representados igualmente os cinco sentidos e as cinco formas sensíveis da matéria.

Assim, os cinco poemas transformam-se numa espécie de ritual ou caminho pelo qual o homem precisa passar para poder, enfim, reafirmar a sua vontade e comungar o desejo.

Para tal, toda a sorte de disfarces se torna necessária, o que se revela bastante eficaz na construção das imagens poéticas. A característica pictórica, tão bem explorada em trabalhos anteriores do autor, amplia-se para um nível sensorial primário, em que cores, cheiros e sensações contrastantes compõem a trama sensível do texto. Mata-se, literal e literariamente, a fome de amor com um verdadeiro banquete, como neste fragmento do poema $D a$ segunda aranha:

\section{E me ofereces um naco \\ de aipo caramelado \\ e um sorvete cremoso \\ me desfalece o palato. ${ }^{23}$}

Em consonância com o regime noturno do imaginário, proposto por Durand, encontram-se aí correspondências estreitas entre o ato alimentar e o ato sexual:

É que, com efeito, nesta imagem da quente intimidade conjugam-se a penetração branda e o acariciante repouso do ventre digestivo e do ventre sexual. A imaginação da descida verifica a intuiç̃o freudiana que faz do tubo digestivo o eixo descendente da libido antes de sua fixação sexual. ${ }^{24}$

O ato alimentar guarda em si, igualmente, o caráter de transubstanciação na ideia do engolimento, da descida
24. DURAND. As estruturas antropológicas do imaginário, $\mathrm{p}$. 202. 
25. DURAND. As estruturas antropológicas do imaginário, $\mathrm{p}$.

26. DURAND. As estruturas antropológicas do imaginário, $\mathrm{p}$ digestiva, o que corresponde perfeitamente ao simbolismo da interiorização, da intimidade, próprio do regime noturno. "É por essa razão que Bachelard pode muito profundamente afirmar que 'o real é antes de tudo um alimento'. Entendemos com isso que o ato alimentar confirma a realidade das substâncias. Porque a 'interiorização ajuda a postular uma interioridade"”. ${ }^{25}$

Um outro recurso imagístico utilizado com frequência é o de listar, em diferentes ocasiões (mas com o mesmo sentido), elementos que dispõem de uma casca ou invólucro exterior que guarda, estrategicamente, um núcleo interno. Alho, alface, noz, são alguns deles. Durand mais uma vez evoca Bachelard para equiparar a simbologia da casca à da concha, como esconderijo, refúgio, uma representação da própria imaginação que faz com que o homem se volte para si mesmo "para viver aí o verdadeiro isolamento, a vida dobrada sobre si mesma, todos os valores do repouso". ${ }^{26}$ Ocorre aí um novo contraste, pois o movimento realizado pelo eu lírico é sempre no sentido de desvendar, descascar ou desfolhar estes elementos, certo de que o faz em se tratando do outro, do objeto do desejo, e jamais em relação a si mesmo. Esta atitude deixa claro que o seu papel nesta caçada amorosa será sempre o do sedutor, e nunca o do seduzido.

Reaparecem menções à inevitável mistura entre o sagrado e o profano, tema que já havia sido enunciado no terceiro poema do livro. Novamente o desejo reúne as imagens de anjo e demônio, que se nivelam e interagem, cada uma representando a face do duplo, flertando com a possibilidade do encontro e do paradoxo. Rescendes a enxofre / e ainda assim eu te quero / mesmo sabendo que o demo / elegeu-te como cetro ${ }^{27}$, ou, ainda, és Jesus Cristo no gosto / Virgem Maria no olfato ${ }^{28}$ assinalam a correspondência entre o ato sexual e referências a elementos das escrituras sagradas, com um propósito de ritualização, como esclarece Eliade:

Ora, essas correspondências antropocósmicas interessam-nos principalmente porque são as "cifras" das diversas situações existenciais. Dizíamos que o homem religioso vive num mundo "aberto" e que, por outro lado, sua existência é "aberta" para o Mundo. Isto é o mesmo que dizer que o homem religioso é acessível a uma série infinita de experiências que poderiam ser chamadas de "cósmicas". Tais experiências são sempre religiosas, pois o Mundo é sagrado. Para chegar a compreendê-las, é preciso ter em mente que as principais funções fisiológicas são suscetíveis de se transformar em sacramentos. Come-se ritualmente, e a alimentação é diversamente valorizada segundo as diferentes religiões e culturas: os alimentos são considerados sagrados, ou um dom da divindade, ou uma oferenda aos deuses do corpo (como é o caso, por exemplo, na Índia). A vida sexual, como vimos, também é ritualizada e, por consequência, assimilada aos fenômenos cósmicos (chuvas, semea-
27. CARVALHO. Bolha de luz, p. 20

28. CARVALHO. Bolha de luz, p. 19
EM TESE
BELO HORIZONTE
N. 2 
29. ELIADE O sagrado e o profano, p. 139. dura) e aos atos divinos (hierogamia Céu-Terra). Por vezes, o casamento é valorizado num plano triplo: individual, socia e cósmico. Por exemplo, entre os Omaha, a aldeia é dividida em duas metades, chamadas respectivamente Céu e Terra. Os casamentos só podem ser realizados entre as duas metades exógamas, e a cada novo casamento repete-se o hieros gamos primordial: a união entre a Terra e o Céu. ${ }^{29}$

É nessa mistura que se nota, mais uma vez, a grande diferença entre a figura do Eros socrático e a do marginal terno de Bolha de luz. Aquele, uma vez que não possuía elemento socia ou religioso algum que lhe proporcionasse o conflito entre a existência e a manifestação do desejo, lançava-se sem culpa alguma ao seu próprio destino: o de obter o máximo de prazer nas relações amorosas. Este, porque vive eternamente dividido entre as convenções e a sua natureza original (a mesma do Eros socrático, porém deformada pelo sentimento de culpa) experimentando a dor provocada pelo conflito de identidade, manifesta de forma conturbada a sua busca do prazer sensual. A certa altura, surge a indagação: Como dar enredo a essa Missal a que eu comungue o desejo $0^{30}$ Esta é a grande preocupação metafísica que atormenta a figura do Eros moderno: ter de manifestar o desejo por vias tortuosas, proibidas.

Como consequência deste embate de forças, emerge, nas descrições da entrega amorosa, uma violência que se tor na a principal veiculadora da fúria erótica, da libertação da agressividade acumulada em virtude da repressão dos instintos. Aqui se verifica a utilização da imagem do diabo como responsável por esta agressividade, pelo desejo de conquistar ou possuir um corpo por meios violentos. É o domínio do inconsciente, onde os desejos mais reprimidos vêm à tona, possibilitando uma quase que total escravização e corrupção através do sexo.

Surge ainda a questão do preconceito, mais nitidamente enunciada em Apojatura, cujo título deixa antever a imagem do casal personificada na figura da ornamentação musical. ${ }^{31}$ Os gatos envergam a natural alusão à independência e sensualidade do comportamento erótico, carregando consigo novamente o contraste entre a luz e a sombra, o permitido e o proibido. Uma vez mais se concebe a ideia da manifestação (homo) erótica como algo que se deve esconder a qualquer custo, sob a pena de se ter o comportamento marcado para sempre pela utilização de epítetos comuns, marcados por símbolos (forca, punhal), conferidos pelos representantes da 'ordem' vigente.

É em Fado que se reafirma a eterna predisposição do homem à sensualidade. Aproximando-se tanto da forma musical - o fado, em que a nostalgia revela a doçura da alma - quanto do significado literal da palavra, o poeta pressente que o destino inexorável do homem é manifestar a sua sexualidade, o seu erotismo, seja ele desse ou daquele jeito.
31. Em música, apojatura é o recurs de se aliar uma ou duas pequenas notas ornamentais precedentes à nota real, da qual retiram próprio valor e acentuação.
EM TESE
BELO HORIZONTE
v. 22
N. 2
MAIO-AGO. 2016
CRUZ. Por um Eros furioso e terno: Uma abordagem poética [...]
P. 197-212 
Por fim, resta uma insubmissão intrínseca inerente ao iniciado nos mistérios do amor e do sexo, essa contradição por demais intrigante em que ao movimento de busca do prazer equivale um outro, o de retraimento, o da recusa em revelar-se totalmente, guardando dentro de si a chave da própria armadilha. Louco, na medida em que busca um sentido maior para a comunhão do amor, o homem se afasta dos demais, trilha um caminho incerto e aproxima-se da sublimação, de um mistério maior que o aguarda em cada experiência vivida.

Ao desafiar a divindade e tentar rivalizar-se com ela, o Eros socrático entra em contato com uma realidade perversa, em que a consciência do real convencionalizado se converte na dura prisão da qual ele tem de escapar para se fazer expressar em sua plenitude essencial. Transformado num Eros moderno, na figura do marginal terno e furioso, cuja doçura universaliza a busca da transcendência sobre os valores cotidianos do sexo e da entrega amorosa, o homem trava conhecimento com os rigores de uma lei social e religiosa que o impede de realizar-se plenamente. É, pois, obrigado a elaborar disfarces para a busca do prazer, para saciar a volúpia de que também é prisioneiro, valendo-se das sombras para expandir sua luz intensa.

Bolha de luz é a luta deste Eros contemporâneo para afirmar a sua própria existência enquanto entidade necessária à germinação da vida, enquanto organismo primordial na gênese do ser humano, de suas paixões e desejos. É a vigência de uma poética altamente sensualizada, em que os limites entre o sagrado e o profano se interpenetram constantemente, ora pendendo para um - o sagrado como necessidade de ritualização da entrega ou de questionamento da culpa - ora para outro - o profano como ruptura definitiva da prisão imposta ao homem pelas convenções sociais.

\section{REFERÊNCIAS}

CARVALHO, Hermínio Bello de. Bolha de luz. Rio de Janeiro: Edição do Autor, 1985

CHEVALIER, Jean; GHEERBRANT, Alain. Dicionário de símbolos 11. ed. Rio de Janeiro: José Olímpio, 1997.

\section{DURAND, Gilbert. As estruturas antropológicas do imaginário:} introdução à arquetipologia geral. Trad. Hélber Godinho. 3. ed. São Paulo: Martins Fontes, 2002.

DURAND, Gilbert. Mito e poesia. In: Campos do imaginário. Org. Danièle Chauvin. Trad. Maria João Batalha Reis. Lisboa: Instituto Piaget, 1996. p. 41-54

ELIADE, Mircea. Mito e realidade. Trad. Pola Civelli. São Paulo: Perspectiva, 1972

ELIADE, Mircea. O sagrado e o profano: a essência das religiões. Trad. Rogério Fernandes. São Paulo: Martins Fontes, 2001 
HAMBURGER, Käte. O gênero lírico. In:

A lógica da

criação literária. Trad. Margot P. Malnic. 2. ed. São Paulo:

Perspectiva, 1986. p. 167-209.

MELLO, Ana Maria Lisboa de. Poesia e imaginário. Porto Alegre: EDIPUCRS, 2002

PAZ, Octávio. A imagem. In:_ Signos em rotação. São

Paulo: Perspectiva, 1996. p. 37-50.

PLATÃO. O banquete - Apologia de Sócrates. Trad. Carlos

Alberto Nunes. 2. ed. rev. Belém: EDUFPA, 2001. 